\title{
Family Support in Caring for Diabetes Mellitus Patient: Patient's Perspective
}

\author{
Indah Wulandari ${ }^{1,3 *}$, Kusnanto Kusnanto ${ }^{1}$, Sony Wibisono ${ }^{2}$, Ani Haryani $^{3}$ \\ ${ }^{1}$ Faculty of Nursing, Universitas Airlangga, Indonesia; ${ }^{2}$ Department of Endocrine, Faculty of Medicine, Universitas Airlangga, \\ Surabaya, Indonesia; ${ }^{3}$ Faculty of Health Science, Universitas Faletehan, Serang, Indonesia Surabaya, Indonesia
}

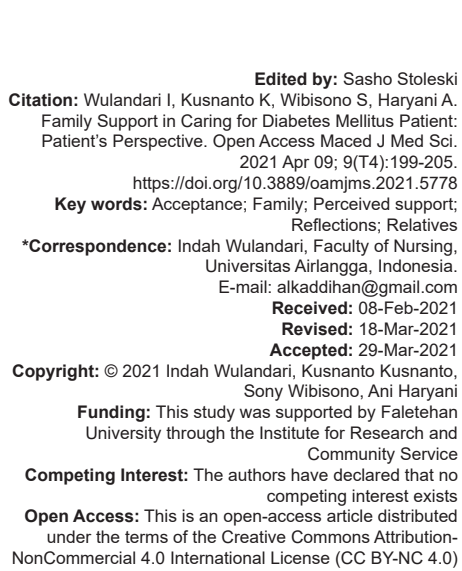

Introduction

The number of diabetes mellitus patients in the world is projected to increase by 204 million (48\%) from 425 million in 2017 to 629 million in 2045 [1]. Indonesia is ranked $6^{\text {th }}$ out of ten countries with the highest number of patients diagnosed with diabetes mellitus in the world, which is ten million people. Most patients diagnosed with diabetes mellitus were aged 20-64 years, amounting to 327 million people compared to those aged 65-99 years with 123 million people [1]. The incidence of diabetes mellitus increases at the age of 55-64 years by around $4.8 \%$, and diabetes mellitus is more experienced by women $(1.7 \%)$ than men $(1.4 \%)$. In addition, the occupation factor (2.0\%) and higher education $(2.5 \%)$ are one of the indicators of increasing the incidence of diabetes mellitus because it is above the prevalence value of diabetes mellitus (1.5\%) [2].

Diabetes mellitus is also estimated to be the cause of death for 4 million patients between the ages of 20 and 79 years in 2017 . The percentage of deaths of patients diagnosed with diabetes mellitus globally reaches $10.7 \%$, higher than the death rate due to HIV/
AIDS infection (1.1 million people), and tuberculosis infection (1.8 million people). The total financing for the care of diabetes mellitus patients (aged 20-79 years) worldwide also increases every year, it is estimated that around 548 billion USD in 2013 to 673 billion USD in 2015 and 727 billion USD in 2017 [1]

Diabetes mellitus is a chronic disease that states with hyperglycemia [1], [3], [4]. The increasing number of diabetes mellitus patients each year also increases morbidity and mortality due to complications arising from diabetes mellitus. After a person is diagnosed with diabetes mellitus, he must do selfcare because most of the care is done at home [5] including diet, blood sugar monitoring, exercise activity, medication, and foot care [6], [7].

Self-care that aims to allow patients to maintain glycemic control rises to complexity [8]. The achievement of glycemic control is the goal of treating diabetes mellitus patients at home and one of which is the achievement in carrying out self-care [9]. Self-care adherence to diabetes mellitus patients is currently not entirely good and optimal [10], [11], [12], [13]. This compliance can be obtained by internal and external factor of the patient. 
External factors that indirectly influence glycemic control in diabetes mellitus patients are social support [14], family support [15], and support for health personnel and the health service system [5], [16]. Several previously described interventions were used to improve the care of diabetes mellitus patients, both individually and involving families in its implementation.

Implementing existing cultural care and adopting individuals diagnosed with diabetes mellitus are considered as daily values while implement selfcare [10], [17]. The results showed that Korean-American immigrant diabetes mellitus patients had difficulty in adjusting the menu according to the type of food habits in their country [11], while traditions from certain ethnicities also increased the risk of diet failure in diabetes mellitus patients [17], [18], [19]. Barriers to implementing diet that improve patients such as diet changes before and after diabetes mellitus diagnosis, balance of food composition, frequency, and food control.

Compliance with self-care also takes advantage of the patient's spiritual values, which have enthusiasm, passion for gaining, belief, hope, and meaning in life [20], [21], [22]. Spirituality influences a person to show behaviors that support their health [23]. The spiritual meaning for a person diagnosed with diabetes mellitus is accepting the disease along with all treatment plans and self-care management, carrying out self-care with sincerity, patience, and "tawakal" or trusting in God's plan because what is lived is part of his daily life, as a part of more worship activities preferred in their belief or religion [20].

The phenomenon found in the field shows that the glycemic controversy of diabetes mellitus patients that is not achieved is not only due to internal factors of the patient but also from external factors, namely, family support. Obviously, the family support received by diabetes mellitus patients varies. The way patients perceive the support they receive will also vary. Positive support given by the family and also positively received by diabetes mellitus patients is also important. Often families feel that they have to provide support but are perceived differently by patients. As a result, there is no good mutual relationship and it has an impact on the treatment of diabetes mellitus patients in the future. This study aimed to explore the perceptions of diabetes mellitus patients on the support provided by their families after diabetes mellitus diagnosis has been enforced.

\section{Methods}

\section{Design}

A phenomenological study using semistructured questions was chosen as the design in this study. The purpose of this approach was to provide an interpretation of family support from the participant's point of view. Data collection using in-depth interviews begins with the question of "what kind of family support do you get after being diagnosed with diabetes mellitus?." The questions then develop based on the responses from the participants.

\section{Setting and sample}

A total of 19 participants were recruited using criteria including being diagnosed with diabetes mellitus for at least 1 year, outpatient, and willing to participate in the study. Data collection was carried out in three primary health centers representing rural and urban areas as well as the demographics of coastal, urban, and mountainous areas. The purpose of selecting sites is to represent the characteristics of the participants.

\section{Data collection and analysis}

Researchers received assistance from three nurses in charge of the non-communicable diseases program at each primary health center. The person in charge of the program played a role in selecting potential participants and providing a place for interviews. Interviews were conducted in three primary health centers before the COVID-19 pandemic. Some of the participants were interviewed using video calls during the COVID-19 pandemic.

The primary researcher conducted semistructured interviews in a private room at the health center. The interview content included views of the family support felt by participants after being diagnosed with diabetes mellitus. Field notes were also collected. Interviews were audio recorded and transcribed verbatim. Interviews were conducted for 40-60 $\mathrm{min}$ each patient.

The study maintains the validity (trustworthiness) data obtained includes credibility (internal validity), transferability (external validity), dependability (reliability), and confirmability (objectivity) to the data obtained from participants.

Data analysis used seven steps of descriptive phenomenological analysis from Colaizzi's including data recognition, identification of significant statements, formulating meanings, grouping themes, developing complete descriptions, producing fundamental structures, and seeking verification of fundamental structures.

The analysis step was carried out to find the themes that emerged from the interviews conducted. In the initial stage of the analysis, the researcher read the existing verbatim transcripts carefully. Table 1 describes the significant statements identification and thematic clusters after we perform the verbatim analysis step. Table 2 describe thematic analysis and theme. 
Table 1: The example of significant statements identification and thematic clusters

\begin{tabular}{|c|c|}
\hline Significant statements identification & Thematic clusters \\
\hline $\begin{array}{l}\text { “... my children's struggles, also my husbands, my } \\
\text { son in-laws, and my grandchildren struggles, right? } \\
\text { They all really take care of me to be healthy huh... } \\
\text { "P9. } \\
\text { "When I See their efforts to take care of me, to cure } \\
\text { me, its touch my heart. They have to work, but they } \\
\text { always took care of me..." P14. }\end{array}$ & Family struggle \\
\hline $\begin{array}{l}\text { “...my children always care about me, especially } \\
\text { when I got sick..." P1. } \\
\text { "When I was got sick, they always ask me to get } \\
\text { some rest, not allow me to do anything..." P16. }\end{array}$ & $\begin{array}{l}\text { Family attention when I } \\
\text { get sick }\end{array}$ \\
\hline $\begin{array}{l}\text { "...my wife knows a lot about my disease, she always } \\
\text { come with me to the primary health center if she } \\
\text { can" P2 }\end{array}$ & The family care \\
\hline $\begin{array}{l}\text { “...my family always help me with everything...my } \\
\text { food, my blood glucose, my medication... whatever } \\
\text { they will do for me, they do their best for me...” P10 }\end{array}$ & $\begin{array}{l}\text { Family help me deal with } \\
\text { illness }\end{array}$ \\
\hline $\begin{array}{l}\text { "they are really take care of me... if night fall and I } \\
\text { get starving, they will allow to eat some snack, they } \\
\text { understand what I want, what I need...And when I got } \\
\text { sick, they always there." }\end{array}$ & Family presence \\
\hline $\begin{array}{l}\text { “...Sometimes I get annoyed when they not allow } \\
\text { me to drink some coffee. I said I don't want to be } \\
\text { banned anymore, how come I can arrange it myself. } \\
\text { Now, my husband and mu children understand me } \\
\text { better..." P7. }\end{array}$ & $\begin{array}{l}\text { Communication is } \\
\text { important to each other }\end{array}$ \\
\hline $\begin{array}{l}\text { "When my wife reminds me about the medication, } \\
\text { especially when she do it in front of the other } \\
\text { people, I feel like angry. So uncomfortable, I don't } \\
\text { want everyone know that I'm sick... I still can be a } \\
\text { productive person, right? Now my wife knows what I } \\
\text { want, and she not annoying me again" P17. }\end{array}$ & \\
\hline $\begin{array}{l}\text { “...my family make me strong, I cannot do anything } \\
\text { without them...” P10. }\end{array}$ & Family is my strength \\
\hline $\begin{array}{l}\text { "When I see my children...they still need me, so I } \\
\text { have to be healthy than now..." P9. }\end{array}$ & \\
\hline $\begin{array}{l}\text { "They always reminds me to present God in my lifr, } \\
\text { especially when I get sick.." P14. } \\
\text { "Thanks to God, when I got sick, I get a fully support } \\
\text { from my wife, she always though me to pray for my } \\
\text { own health..." }\end{array}$ & $\begin{array}{l}\text { Reminds me to god } \\
\text { presenting }\end{array}$ \\
\hline $\begin{array}{l}\text { "my partner reminds me to always worship when I } \\
\text { sick"P7. } \\
\text { "only God gives us pain and then heal. As long as we } \\
\text { are grateful for what happened, even though we are } \\
\text { sick, it doesn't feel heavy anymore. Especially if there } \\
\text { is a family who accompanies it }\end{array}$ & Spiritual faith from family \\
\hline $\begin{array}{l}\text { "They help me when I have to do a worship. I got } \\
\text { obese for many years, so hard to worship and pray, } \\
\text { someday my husband was made a special chair for } \\
\text { me to do my worship" P9. }\end{array}$ & $\begin{array}{l}\text { Family support to } \\
\text { spiritual need }\end{array}$ \\
\hline $\begin{array}{l}\text { "I surrender to God's decision about my illness" P9 } \\
\text { "Healing belongs to God, I leave it all to him... P14. }\end{array}$ & $\begin{array}{l}\text { Give up on God's } \\
\text { decision }\end{array}$ \\
\hline
\end{tabular}

"Healing belongs to God, I leave it all to him.." P14.

*P_number: Number of participant

Then, the researcher extracted significant statements that pertain to the phenomenon which were used for the next step in formulating meaning from significant statements. The researcher then aggregated the meaning that had been formulated into theme clusters and themes. Then researchers developed an exhaustive description of the phenomenon's essential structure or essence. The next step was making a

Table 2: Thematic cluster and theme

\begin{tabular}{ll}
\hline Thematic cluster & Theme \\
\hline Family attention when I get sick & $\begin{array}{l}\text { The perceptions on family } \\
\text { function }\end{array}$ \\
$\begin{array}{l}\text { Family attention when I get sick } \\
\text { The family care }\end{array}$ & \\
Family help me deal with illness & $\begin{array}{l}\text { The perceptions on the role of } \\
\text { the family }\end{array}$ \\
$\begin{array}{l}\text { Family presence } \\
\text { Comily help me anytime }\end{array}$ & $\begin{array}{l}\text { The perceptions on family } \\
\text { Family is my strength }\end{array}$ \\
$\begin{array}{l}\text { Reminds me to god presenting } \\
\text { Spiritual faith from family }\end{array}$ & $\begin{array}{l}\text { The perception on spiritual } \\
\text { Family support to spiritual need }\end{array}$ \\
Give up on god's decision & \\
\hline
\end{tabular}

description of fundamental structure of the phenomenon which was subsequently generated. The last step was validating the findings of the study through participant feedback completing the analysis.

\section{Ethical approval}

We obtained ethics from the Health Research Ethics Commission of the Faculty of Nursing Universitas Airlangga number 1912-KEPK.

\section{Results}

\section{Participant demographic}

Table 3 shows the 19 participants, the majority of participants were over 45 years old, female, diagnosed $<10$ years old, and lived with their nuclear family. The results of the study also showed that out of 19 participants, nine participants did not work, four participants had a trading job, and six participants worked as employees both in state and private instantaneous. The youngest age of the participants was 19 years, and the oldest age was 70 years. The minimum time the patient was diagnosed with diabetes mellitus was 1 year (5 participants), and the longest was 20 years (1 participant). Eight participants live in rural areas and 11 participants live in urban areas.

Table 3: Participant's demographic

\begin{tabular}{|c|c|c|c|c|c|c|}
\hline$P$ & Age & Gender & $W^{a}$ & $1 D^{b}$ & $\mathrm{FT}^{\circ}$ & $\mathrm{LA}^{\mathrm{d}}$ \\
\hline 1 & 59 & Female & $\mathrm{NE}^{\mathrm{at}}$ & 9 & $\mathrm{NF}^{\mathrm{ct}}$ & Rural \\
\hline 2 & 45 & Male & $\mathrm{NE}^{\mathrm{a} 1}$ & 1 & $\mathrm{NF}^{\mathrm{c} 1}$ & Rural \\
\hline 3 & 50 & Female & $\mathrm{NE}^{\mathrm{a} 1}$ & 1 & $\mathrm{NF}^{\mathrm{c} 1}$ & Rural \\
\hline 4 & 42 & Female & $\mathrm{NE}^{\mathrm{a} 1}$ & 1 & $\mathrm{NF}^{\mathrm{c} 1}$ & Rural \\
\hline 5 & 48 & Female & $\mathrm{NE}^{\mathrm{a} 1}$ & 1 & $\mathrm{NF}^{\mathrm{c} 1}$ & Rural \\
\hline 6 & 56 & Female & $\mathrm{NE}^{\mathrm{a} 1}$ & 8 & $\mathrm{NF}^{\mathrm{c1}}$ & Rural \\
\hline 7 & 60 & Female & $\operatorname{Tra}^{\mathrm{a} 2}$ & 10 & $\mathrm{NF}^{\mathrm{c} 1}$ & Urban \\
\hline 8 & 65 & Male & $\mathrm{CS}^{\mathrm{a} 3}$ & 20 & $\mathrm{NF}^{\mathrm{c1}}$ & Urban \\
\hline 9 & 52 & Female & $\mathrm{NE}^{\mathrm{a} 1}$ & 2 & $\mathrm{EF}^{\mathrm{c} 2}$ & Rural \\
\hline 10 & 44 & Female & $\mathrm{CS}^{\mathrm{a} 3}$ & 5 & $\mathrm{NF}^{\mathrm{c} 1}$ & Urban \\
\hline 11 & 46 & Male & $\mathrm{GE}^{\mathrm{a} 4}$ & 2 & $\mathrm{NF}^{\mathrm{c1}}$ & Urban \\
\hline 12 & 70 & Female & $\mathrm{NE}^{\mathrm{a} 1}$ & 15 & $\mathrm{EF}^{\mathrm{c} 2}$ & Urban \\
\hline 13 & 19 & Female & $\mathrm{St}^{\mathrm{a}^{5}}$ & 2 & $\mathrm{NF}^{\mathrm{c} 1}$ & Urban \\
\hline 14 & 70 & Female & $\mathrm{NE}^{\mathrm{a} 1}$ & 3 & $\mathrm{EF}^{\mathrm{c} 2}$ & Urban \\
\hline 15 & 50 & Female & $\operatorname{Tra}^{\mathrm{a} 2}$ & 1 & $\mathrm{EF}^{\mathrm{c} 2}$ & Urban \\
\hline 16 & 52 & Female & $\mathrm{Tra}^{\mathrm{a} 2}$ & 1 & $\mathrm{NF}^{\mathrm{c} 1}$ & Rural \\
\hline 17 & 49 & Male & Lect $^{26}$ & 3 & $\mathrm{NF}^{\mathrm{c} 1}$ & Urban \\
\hline 18 & 54 & Male & $\mathrm{Tra}^{\mathrm{a}^{2}}$ & 10 & $\mathrm{NF}^{\mathrm{c} 1}$ & Urban \\
\hline 19 & 54 & Female & Lect $^{a 6}$ & 18 & $\mathrm{NF}^{\mathrm{c} 1}$ & Urban \\
\hline
\end{tabular}

\section{Source of family support}

The question asked to find out the support received by participants is "who has a role to provide support after you are diagnosed with diabetes?." Almost all participants answered that that support was obtained from their family members/nuclear family, either those who live with the participants or those who live around the participants. The support provided was mostly obtained from nuclear families, namely, the children and the participants' spouse. However, support 
from outside the nuclear family was also found, such as from siblings or grandchildren. It can be evidenced from the following answers from the participants:

All my children ma'am. Everyone reminds me. Even though they are far away, they are still calling. The children in Bandung are likely to remember (participant 14).

My wife is also very respectful, attentive, sometimes she reminds me (participant 17).

My younger brother who is in Tangerang, he said, 'Don't think about the costs, that's my responsibility (participant 2).

The support is come from my parents, of course, both ways (participant 13).

\section{The perceptions on family function}

The results showed that according to the family participants, they have carried out family functions as health-care providers. The participants received attention related to care since they were diagnosed with diabetes mellitus from their closest family, such as a partner or child. The results of the research are seen in the following statement:

The struggle of the children, the struggle of the husband, the in-laws, the grandchildren, right? They all really took care of me to be healthy, huh (participant 9).

The one who put concerned here, her name is Sri, she is not married. She works at gas station. She is who always take care of me, always come with to see a doctor (participant 16).

\section{The perceptions on the role of the family}

The role of the family that stands out in this study that is felt by the participants is the role of therapy. This role occurs when a member of the family experiences illness. The therapeutic role is felt not only by the participants physically but also psychologically and spiritually. The family becomes the closest person to provide care to the participants. The results of this research can be validated from the following statements:

My children have already paid attention to me. Especially when I am sick (participant 1).

It's too bad everyone (kids), just cry ...'poor mother,' he said. InshaAllah (surrender to God's decision), just pray for recovery, just ask the children to pray, let me get together again, get well.... To get well (participant 15).

The role of family therapeutics received by participants supports participants in carrying out diabetes mellitus treatment at home. This can be seen from the following participant statements:

She knows (wife), if you have diabetes you have to reduce your rice, my wife also likes accompany me here (go to the health center) when she is on vacation (participant 2).
The wife is a little bit protective (chuckles), especially when eating, but now also changes this pattern ... the cooking pattern is like that ... Then my wife also reminds me when to take the medicine (participant 15).

\section{received}

\section{The perceptions on family support}

The support given by the family to the patient has a big impact on the participants. The participants become stronger, more grateful, and accept their condition because of the support provided by their families. The participants' perceptions about the family support received are shown in the following statements:

They (family member) give me support 100 percent, no, maybe one thousand percent of times (laughs happily). Moreover, my children... especially all of them, the youngest, the first child, the husband. Sometimes my husband is silent, right, that's his own way ... yes ... cares for me in his own way. Help me Alhamdulillah (feel grateful). Even my grandchildren who are still small in their own way are always make me happy, even with words... even those who are sick become strong nanny. The one who was sick was finally ... oh my God ... I said, until that much (remembering the family sacrifice) (participant 9).

Previously, I refused, I didn't accept diabetes, I often complained, "oh why is this like this." Like screaming. Children who always remind me to pray, always pray, all kinds of things, are calmer now (participant 14).

\section{the family}

\section{The perception on spiritual support from}

This study found one theme that was obtained several times from the participants, namely, the spiritual support provided by the family to the participants. This spiritual support is what makes the participants sincere in accepting their illness and living their lives more calmly. The following statements were made by participants regarding the spiritual support:

Grateful because that one child always accompanies me, prays for me, reminds me to worship (participant 15).

So the support capacity is extraordinary from the family, so it is very internal that can give a very strong giroh (the meaning of spirit in Islam). Alhamdulillah (feel grateful) it continues to strengthen sincerity (participant 19).

\section{Discussion}

Diabetes mellitus is a chronic disease and requires many years of treatment [3]. The standard 
of care for diabetes mellitus patients includes management of diet, activity, medication, and glycemic control [24], [25]. The results of previous studies show that it is difficult for patients to undergo such treatment, so they need support from various parties, one of which is from their family [26], [27], [28], [29], [30].

One of the supports received by diabetes mellitus patients in their care at home comes from their families. Family support received by the patients will increase patient compliance in their care at home [10], [31]. The assistance needed by diabetes mellitus patients at home includes diet [30], [32] assistance for daily activities, health care, financial support, attention, and problem solving [32] as well as in activities, blood glucose monitoring, and medication [33]. Diabetes mellitus patients who get support from their families feel better due to emotional and behavioral support [34]. The results showed that most of the participants lived with the nuclear family and received care from their children or partners. The care that participants felt was starting from care when they were sick, attention, and support for running diet.

Every family has its own process in overcoming health problems in the family, both regarding the health of family members and the health of the family as a whole. The process in the family can have a big impact on the health status in the family [35]. The family has various roles among family members, such as provider roles (breadwinners), housekeeper and care roles (caring for the house and children), socialization roles (socialization and family interactions), sex roles (reproduction), and therapeutic roles (caregiver roles). The role that each family member plays in accordance with the developmental conditions in the family, aims to adapt and solve problems one of which is health problems in the family [35].

The support felt by diabetes mellitus the patients helps patients accept and adapt to their sick conditions [35], [36]. Although the patient may not show certain clinical symptoms, the chronic condition experienced by diabetes mellitus patients must occur and has impact on their physical and psychological health. Therefore, the support received, especially from the family, will help the patients accept and immediately adapt to their sick condition [27], [31], [37], [38].

The results of the study found four main themes about participants' perceptions regarding diabetes mellitus. The first and second themes are the participants' perceptions on the function and role of the family after the participants were diagnosed with diabetes mellitus. The analysis of the two themes was that the participants felt that after being diagnosed with diabetes, the participants needed a specific function and role from the accompanying family. These specific functions and roles are related to the function of providing healthcare by the family and the emergence of the sick role of the participants who need a therapeutic role from the family. These two things are related to each other in the context of the relationship in the family. Every family who has a sick family member will demonstrate both functions and roles mentioned in efforts to deal with and resolve health problems [35], [39].

The third theme found was the participants' perceptions on the support they received from their families. Most of the participants needed psychological strengthening in the form of motivation and emotional support from their families to deal with their condition. This motivational and emotional support makes the participants strong in accepting and adapting to their conditions. In addition, most participants are in the productive age range and have children who are at school age or at the end of school. This condition becomes a separate reinforcement for the participants to accept and immediately adapt to the conditions. Mostly, the participants accept their condition because of their children or family, the participants still want to see their offspring succeed. Thus, they grow strong to make peace with diabetes mellitus. The acceptance of patients for their disease is certainly not easy and requires support from the family. The reciprocal relationship between family members in dealing with health problems in the family makes each family unique. The ability of the family to use the resources owned by the family to solve health problems in the family is an important point [39], [40], [41].

The fourth theme found was the participants' perceptions on spiritual support from the family. In this study, all participants involved are Muslims. The trust and values in the family influence family behavior in caring for family members who are sick, such as diabetes mellitus patients [35], [36]. The ease with which diabetes patients accept and make peace with their disease cannot be separated from their spiritual role [42], [43]. In this study, all participants expressed their surrender to God and took care seriously as one of the values of the worship. Finally, all participants gave everything to God, but almost all participants experienced rejection when they were diagnosed with diabetes mellitus. This condition is common, especially in participants who are in the productive age range. The confusion about the disease's impact on productivity is the main reason besides the fear of complications and death.

The previous studies have shown a link between spirituality and a person's acceptance of their illness [21], [44]. When someone is sick, it is only natural that he tries to treat himself to a doctor or other treatment. The effort made to seek this treatment is a form of acceptance of the disease being experienced. A person's acceptance of the pain he experiences is based on a sense of sincerity and submission to God's destiny, namely the illness he experiences. This is a form of complete submission of a creature to its creator [20], [22], [45]. The worship in the form of routine care, especially for patients with chronic diseases such as diabetes mellitus, can become a habit or culture in the family. As a result, in the end, self-care habits such as 
maintaining diet, routine physical activity, and glycemic control and adhering to medication will be the main parts in treating diabetes patients will be accepted as a form of worship in a spiritual context.

\section{Conclusion}

This study concluded that family support is needed for diabetes mellitus patients to support their care at home. The greatest support comes from the nuclear family. In addition to physical support, spiritual support is also needed to strengthen patients for long-term treatment. Future studies can quantitatively examine the impact of family support on diabetes mellitus patient adherence and quality of life.

\section{Acknowledgments}

We would like to express our gratitude to all participants, the person in charge of the NonCommunicable Disease Program at Baros Health Centre, Pontang Primary health center, and Kramatwatu Health Centre. This research was funded by the Faletehan University through the Institute for Research and Community Service.

\section{References}

1. International Diabetes Federation. IDF Clinical Practice Recommendations for Managing Type 2 Diabetes in Primary Care. International Diabetes Federation. Brussels, Belgium: International Diabetes Federation; 2017.https://doi. org/10.1016/j.diabres.2020.108029

2. Badan Penelitian dan Pengembangan Kesehatan. Riset Kesehatan Dasar (RISKESDAS) 2013. Laporan Nasional 2013; 2013.

3. Smeltzer SC, Bare BG, Hinkle JL, Kerry HC, Garret TM. Brunner and Suddarth's Text Book of Medical Surgical Nursing. Brunner LS. Brunner \& Suddarth's textbook of medical-surgical nursing. Lippincott Williams \& Wilkins; 2010. p. 151-7.

4. Powers MA, Bardsley JK, Cypress M, Funnell MM, Harms D, Hess-Fischl A, et al. Diabetes self-management education and support in adults with Type 2 diabetes: A consensus report of the American diabetes association, the association of diabetes care and education specialists, the academy of nutrition and dietetics, the American academy. Diabetes Care. 2020;43(7):1636-49. https://doi.org/10.2337/dci20-0023

PMid:32527651

5. Grant JS, Steadman LA. Barriers to diabetes self-management among rural individuals in the workplace. Work Heal Saf. 2016;64(6):243-8. https://doi.org/10.1177/2165079916628877 PMid:27016376
6. Soto SC, Louie SY, Cherrington AL, Parada H, Horton LA, Ayala GX. An ecological perspective on diabetes self-care support, self-management behaviors, and hemoglobin A1C among latinos. Diabetes Educ. 2015;41(2):214-23. https://doi. org/10.1177/0145721715569078 PMid:25656696

7. Yang F, Pang JS, Cheng WJ. Self-care adherence and psychological functioning of older patients with Type 2 diabetes: Effects of persuasion, social pressure, and self-efficacy. J Clin Psychol Med Settings. 2016;23(4):389-401. https://doi. org/10.1007/s10880-016-9470-y PMid:27738847

8. Gomes LC, Coelho AC, dos Gomides DS, Foss-Freitas MC Foss MC, Pace AE. Contribution of family social support to the metabolic control of people with diabetes mellitus: A randomized controlled clinical trial. Appl Nurs Res. 2017;36:68-76. https:// doi.org/10.1016/j.apnr.2017.05.009

PMid:28720242

9. Brass BJ, Abelev Z, Liau EP, Poretsky L. Principles of diabetes mellitus. $2^{\text {nd }}$ ed. Poretsky L, editor. Principles of Diabetes Mellitus. New York: Springer; 2010. p. 181-201. https://doi. org/10.1007/978-0-387-09841-8

10. Mansyur CL, Rustveld LO, Nash SG, Jibaja-Weiss ML. Social factors and barriers to self-care adherence in Hispanic men and women with diabetes. Patient Educ Couns. 2015;98(6):805-10. https://doi.org/10.1016/j.pec.2015.03.001

PMid:25819551

11. Joo JY, Lee H. Barriers to and facilitators of diabetes selfmanagement with elderly Korean-American immigrants. Int Counc Nurses. 2016;63(2):277-84. https://doi.org/10.1111/ inr. 12260

PMid:26970224

12. Ansari RM, Hosseinzadeh $H$, Harris $M$, Zwar N. Selfmanagement experiences among middle-aged population of rural area of Pakistan with Type 2 diabetes: A qualitative analysis. Clin Epidemiol Glob Health 2018;(2018):1-11. https:// doi.org/10.21203/rs.2.14605/v1

13. Sina M, Graffy J, Simmons D. Associations between barriers to self-care and diabetes complications among patients with Type 2 diabetes. Diabetes Res Clin Pract. 2018;141:126-31. https:// doi.org/10.1016/j.diabres.2018.04.031

PMid:29689320

14. Wu SF, Lee MC, Liang SY, Lu YY, Wang TJ, Tung HH. Effectiveness of a self-efficacy program for persons with diabetes: A randomized controlled trial. Nurs Health Sci. 2011;13(3):33543. https://doi.org/10.1111/j.1442-2018.2011.00625.x PMid:21812879

15. Shawon MS, Hossain FB, Adhikary G, Das Gupta R, Hashan MR, Rabbi MF, et al. Attitude towards diabetes and social and family support among Type 2 diabetes patients attending a tertiary-care hospital in Bangladesh: A crosssectional study. BMC Res Notes. 2016;9(1):286. https://doi. org/10.1186/s13104-016-2081-8

PMid:27230084

16. Okemah J, Peng J, Quiñones M. Addressing clinical inertia in Type 2 diabetes mellitus: A review. Adv Ther. 2018;35(11):173545. https://doi.org/10.1007/s12325-018-0819-5 PMid:30374807

17. El Masri D, Koscielniak N, Piatt G, DiZazzo-Miller R, Arnetz J, Jaber LA. Barriers and facilitators to perceived diabetes selfmanagement in Arab American patients with diabetes. Prim Care Diabetes. 2020;14(3):232-8. https://doi.org/10.1016/j. pcd.2019.09.002 PMid:31575470

18. Coser A, Sittner KJ, Walls ML, Handeland T. Caregiving Stress 
among American Indians with Type 2 diabetes: The importance of awareness of connectedness and family support. J Fam Nurs. 2018;24(4):621-39. https://doi.org/10.1177/1074840718810550 PMid:30497320

19. Schure M, Goins RT, Jones J, Winchester B, Bradley V. Dietary beliefs and management of older American Indians with Type 2 diabetes. J Nutr Educ Behav. 2019;51(7):826-33. https://doi. org/10.1016/j.jneb.2018.11.007 PMid:30579895

20. Meier A, O'Connor TS, Vankatwyk PL. Spirituality Health: Multidisciplinary Explorations. Ontario, Canada: Wilfrid Laurier University Press; 2005. p. 1-316.

21. Salomé GM, Pereira VR, Ferreira LM. Spirituality and subjective wellbeing in patients with lower-limb ulceration. J Wound Care. 2014;22(5):230-6. https://doi.org/10.12968/jowc.2013.22.5.230 PMid:23702719

22. Yusuf A, Nihayati HE, Iswari MF, Okviansanti F. Kebutuhan Spiritualitas. Jakarta: Mitra Wacana Media; 2016.

23. National Institute on Aging Working Group. Measurement of Religiousness/Spirituality for Use in Health Research. National Institute on Aging Working Group; 1999.

24. International Diabetes Federation. IDF Diabetes Atlas. $8^{\text {th }}$ ed. International Diabetes Federation; 2017.

25. American Diabetes Association. 2. Classification and diagnosis of diabetes: Standards of medical care in diabetes-2018. Diabetes Care. 2018;41(1):13-27. https://doi.org/10.2337/ dc19-s002 PMid:29222373

26. Al-Khawaldeh OA, Al-Hassan MA, Froelicher ES. Self-efficacy, self-management, and glycemic control in adults with Type 2 diabetes mellitus. J Diabetes Complications. 2012;26(1):10-6. https://doi.org/10.1016/j.jdiacomp.2011.11.002 PMid:22226484

27. Ahola AJ, Groop PH. Barriers to self-management of diabetes. Diabet Med. 2013;30(4):413-20. https://doi.org/10.1111/ dme.12105 PMid:23278342

28. Baek RN, Tanenbaum ML, Gonzalez JS. Diabetes burden and diabetes distress: The buffering effect of social support. Ann Behav Med. 2014;48(2):145-55. https://doi.org/10.1007/ s12160-013-9585-4

PMid:24550072

29. Simon-Tuval T, Shmueli A, Harman-Boehm I. Adherence to selfcare behaviors among patients with Type 2 diabetes-the role of risk preferences. Value Health. 2016;19(6):844-51. https://doi. org/10.1016/j.jval.2016.04.003 PMid:27712713

30. Mostafavi-Darani F, Zamani-Alavijeh F, Mahaki B, Salahshouri A. Exploring the barriers of adherence to dietary recommendations among patients with Type 2 diabetes: A qualitative study in Iran. Nurs Open. 2020;7(6):1735-45. https://doi.org/10.1002/ nop2.558

\section{PMid:33072357}

31. Mayberry LS, Harper KJ, Osborn CY. Family behaviors and Type 2 diabetes: What to target and how to address in interventions for adults with low socioeconomic status. Chronic IIIn. 2016;12(3):199-215. https://doi. org/10.1177/1742395316644303

PMid:27099387

32. Kristianingrum ND, Wiarsih W, Nursasi AY. Perceived family support among older persons in diabetes mellitus selfmanagement. BMC Geriatr. 2018;18(Suppl 1):304. https://doi. org/10.1186/s12877-018-0981-2

PMid:30563474

33. Ojewale LY, Oluwatosin AO, Fasanmade AA, Odusan O. A survey on patients' characteristics, perception of family support and diabetes self-management among Type 2 diabetes patients in South-West Nigeria. Nurs Open. 2019;6(2):208-15. https:// doi.org/10.1002/nop2.236

PMid:30918673

34. Kanbara S, Taniguchi H, Sakaue M, Wang DH, Takaki J, Yajima Y, et al. Social support, self-efficacy and psychological stress responses among outpatients with diabetes in Yogyakarta, Indonesia. Diabetes Res Clin Pract. 2008;80(1):56-62. https:// doi.org/10.1016/j.diabres.2007.12.015 PMid:18262305

35. Kaakinen JR, Coehlo DP, Gedaly-Duff V, Hanson SM, Kaakinen JR, Gedaly-Duff V, et al. Family Health Care Nursing: Theory, Practice, and Research. $4^{\text {th }}$ ed., Vol. 74. Philadelphia, PA: Public Health, F.A Davis Company; 2010. p. 53-5. https:// doi.org/10.1177/1074840710383274

36. Friedman MM, Bowden VR, Jones EG. In: Tiar E, editor. Buku Ajar Keperawatan Keluarga. $5^{\text {th }}$ ed. Jakarta: EGC; 2010. p. 1-664.

37. Keogh KM, Smith SM, White P, McGilloway S, Kelly A, Gibney J, et al. Psychological family intervention for poorly controlled tType 2 diabetes. Am J Manag Care. 2011;17(2):105-13. PMid:21473660

38. Yue $\mathrm{P}$, Lamb KV, Chen X, Wang $\mathrm{Y}$, Xiao S, Feng $\mathrm{X}$, et al. Identification of family factors that affect self-management behaviors among patients with Type 2 diabetes: A qualitative descriptive study in Chinese communities. J Transcult Nurs. 2019;30(3):250-9. https://doi.org/10.1177/1043659618793713 PMid:30132743

39. Neufeld A, Harrison M. Nursing and Family Caregiving: Social Support and Nonsupport. New York: Springer Publishing Company; 2010.

40. Fleury J, Keller C, Perez A. Social support theoretical perspective. Geriatr Nurs. 2009;30(2 Suppl):11-4. PMid:19345858

41. Martz E. Coping with Chronic Illness and Disability Theoretical, Empirical, and Clinical. Tennessee USA: Springer; 2007.

42. Levin J. God, Faith, and Health: Exploring the SpiritualityHealing Connection. New York: John Wiley and Sons Ltd.; 2001. p. 256.

43. Wright SG. Reflections on Spirituality and Health. London, Philadelphia, PA: WHURR Publishers; 2005. p. 254.

44. Polisetty A, Sheela. Factors influencing spirituality. losr J Bus Manag 2017;19(9):38-42.

45. Young C, Koopsen C. Spiritualitas, Kesehatan, dan Penyembuhan. Pertama. Medan: Bina Media Perintis; 2007. p. 1-312. 